\title{
Publisher Correction to: An increase of phosphatidylcholines in follicular fluid implies attenuation of embryo quality on day 3 post-fertilization
}

Ju Wang ${ }^{1,3+}$, Wei Zheng ${ }^{2 \dagger}$, Shuoping Zhang ${ }^{2+}$, Keqiang Yan ${ }^{1,3}$, Miao Jin², Huiling Hu ${ }^{4}$, Zhen Ma ${ }^{1,3}$, Fei Gong ${ }^{2,4}$, Guangxiu Lu ${ }^{2,4}$, Yan Ren ${ }^{1,3}$, Liang Lin ${ }^{3}$ Ge Lin ${ }^{2,4}$, Liang $\mathrm{Hu}^{2,4^{*}}$ and Siqi Liu ${ }^{1,3^{*}}$

Publisher Correction to: BMC Biol 19, 200 (2021)

https://doi.org/10.1186/s12915-021-01118-w

Following publication of the original article [1], the authors noted errors in the affiliation list and affiliation assignment due to a typesetting mistake. The correct affiliation list and affiliation assignment is reflected in this Correction article and the original article [1] has been corrected.

\begin{abstract}
Author details
'College of Life Sciences, University of Chinese Academy of Sciences, Beijing 100049, China. ${ }^{2}$ Clinical Research Center for Reproduction and Genetics in Hunan Province, Reproductive and Genetic Hospital of CITIC-XIANGYA, Changsha 410008, China. ${ }^{3}$ BGI-Shenzhen, Shenzhen 518083, China. ${ }^{4}$ Institute of Reproductive and Stem Cell Engineering, School of Basic Medical Science, Key Laboratory of National Health and Family Planning Commission, Central South University, Changsha 410008, Hunan, China.
\end{abstract}

Published online: 02 November 2021

\section{Reference}

1. Wang, et al. An increase of phosphatidylcholines in follicular fluid implies attenuation of embryo quality on day 3 post-fertilization. BMC Biol. 2021;19: 200. https://doi.org/10.1186/s12915-021-01118-w.

The original article can be found online at https://doi.org/10.1186/s12915021-01118-w.

*Correspondence: lianghu7@gmail.com; siqiliu@genomics.cn

${ }^{\dagger}$ Ju Wang, Wei Zheng, and Shuoping Zhang are joint first authors.

${ }^{2}$ Clinical Research Center for Reproduction and Genetics in Hunan Province,

Reproductive and Genetic Hospital of CITIC-XIANGYA, Changsha 410008,

China

${ }^{1}$ College of Life Sciences, University of Chinese Academy of Sciences, Beijing 100049, China

Full list of author information is available at the end of the article

\section{Publisher's Note}

Springer Nature remains neutral with regard to jurisdictional claims in published maps and institutional affiliations.

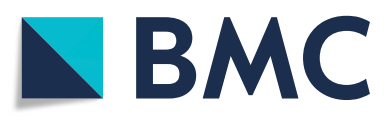

() The Author(s). 2021 Open Access This article is licensed under a Creative Commons Attribution 4.0 International License, which permits use, sharing, adaptation, distribution and reproduction in any medium or format, as long as you give appropriate credit to the original author(s) and the source, provide a link to the Creative Commons licence, and indicate if changes were made. The images or other third party material in this article are included in the article's Creative Commons licence, unless indicated otherwise in a credit line to the material. If material is not included in the article's Creative Commons licence and your intended use is not permitted by statutory regulation or exceeds the permitted use, you will need to obtain permission directly from the copyright holder. To view a copy of this licence, visit http://creativecommons.org/licenses/by/4.0/. The Creative Commons Public Domain Dedication waiver (http://creativecommons.org/publicdomain/zero/1.0/) applies to the data made available in this article, unless otherwise stated in a credit line to the data. 